\title{
Granular cell tumour of the bronchus: bronchoscopic and clinical features
}

\author{
OSCAR G HERNANDEZ, EDWARD F HAPONIK, WARREN R SUMMER \\ From the Department of Medicine, Section on Pulmonary-Critical Care Medicine, Louisiana State University \\ Medical Center, New Orleans, USA
}

ABSTRACT Granular cell tumours are uncommon, generally benign neoplasms of uncertain origin that occasionally affect the tracheobronchial tree. Their incidence seems to be increasing, despite the fact that such tumours are rarely suspected on clinical grounds or bronchoscopic appearance. Here we describe three cases of endobronchial granular cell tumours, one of which regressed spontaneously after biopsy, and review previous accounts of their bronchoscopic and clinical features.

Before 1975 only 40 cases of endobronchial granular cell tumours had been reported. During the past 10 years, however, the number of reports has increased to more than 90 . Although this increased reporting might reflect a real increase in the frequency of such tumours, the more widespread use of fibreoptic bronchoscopy, recognition of the subtle tracheobronchial abnormalities, and a more thorough elucidation of the tumour's pathological characteristics are probably contributing factors. Nevertheless, this diagnosis is rarely entertained when endobronchial abnormalities are found. Our report should alert the clinician and bronchoscopist to the incidence and features of these lesions.

\section{Case reports}

CASE 1

A 59 year old man was admitted after two days of producing purulent, blood streaked sputum. Two months previously he had been treated at another hospital for pneumonia in the upper lobe of the right lung. He had a history of cigarette smoking (40 pack years) and chronic obstructive pulmonary disease had been diagnosed previously. He reported having had brief, intermittent episodes of producing blood streaked sputum for several years before admission. Physical examination showed a healthy looking man with normal vital signs. There was mild finger clubbing and crackles were heard posteriorly at mid level

Address for reprint requests: Dr O G Hernandez, PulmonaryCritical Care Medicine, Louisiana State University Medical Center, 1542 Tulane Avenue, New Orleans, LA 70112, USA.

Accepted 30 June 1986 over the right lung. The remainder of the examination showed nothing remarkable. Fibreoptic bronchoscopy showed old blood within the tracheobronchial tree. Although no active bleeding was seen, a fourth generation bronchus of the right upper lobe was occluded by a small, lobulated, pale grey nodular tumour. Forceps biopsy yielded material with histological appearances of granular cell tumour. No other tracheobronchial lesions were noted, and the patient underwent surgical excision of the mass by lobectomy.

\section{CASE 2}

A 61 year old man, an alcoholic, was admitted to another hospital with pneumonia and atelectasis of the right upper lobe. Fibreoptic bronchoscopy showed normal appearances in the right upper lobe, but a small, pale, nodular tumour was found in the left mainstem bronchus. Biopsy yielded material with histological appearances consistent with granular cell tumour. No treatment was given at that time, and the patient was lost to follow up. Eight years later he was readmitted to hospital with left sided weakness and focal seizures. A mass was noted in the left upper lobe on chest radiography and computed tomography of the brain showed two nodules consistent with right parietal lobe metastatic disease. The patient was then transferred to our hospital for further management. No endobronchial lesions were found on repeat fibreoptic bronchoscopy, and biopsy at the normal appearing site of the previous granular cell tumour showed no residual tumour. Percutaneous needle biopsy of the pulmonary mass yielded material with histological features of large cell carcinoma of the lung. 
CASE 3

A 48 year old man was admitted for evaluation of a mass in the upper lobe of the right lung. He reported a $9 \mathrm{~kg}$ weight loss during the previous four months and a three month history of cough productive of scant whitish sputum. Chest radiography showed a $6.5 \mathrm{~cm}$ mass occupying the upper lobe of the right lung, but no mediastinal tumour was evident. Bronchoscopy showed features of extrinsic compression but no endobronchial obstruction. In the posterior basal segment of the right lung, however, there was a nodular, pale, grey lobulated lesion $0.5 \mathrm{~cm}$ in diameter. Forceps biopsy material had appearances consistent with granular cell tumour. No other lesions were found, and the patient's right lung was later removed. The surgical specimen included a lesion with appearances characteristic of granular cell tumour and large cell carcinoma of the right upper lobe (figure).

\section{Discussion}

Abrikossoff in 1926 was the first to describe granular cell tumour in a series of five patients with tumours of the tongue. ${ }^{1}$ Since that first description, nearly 1000

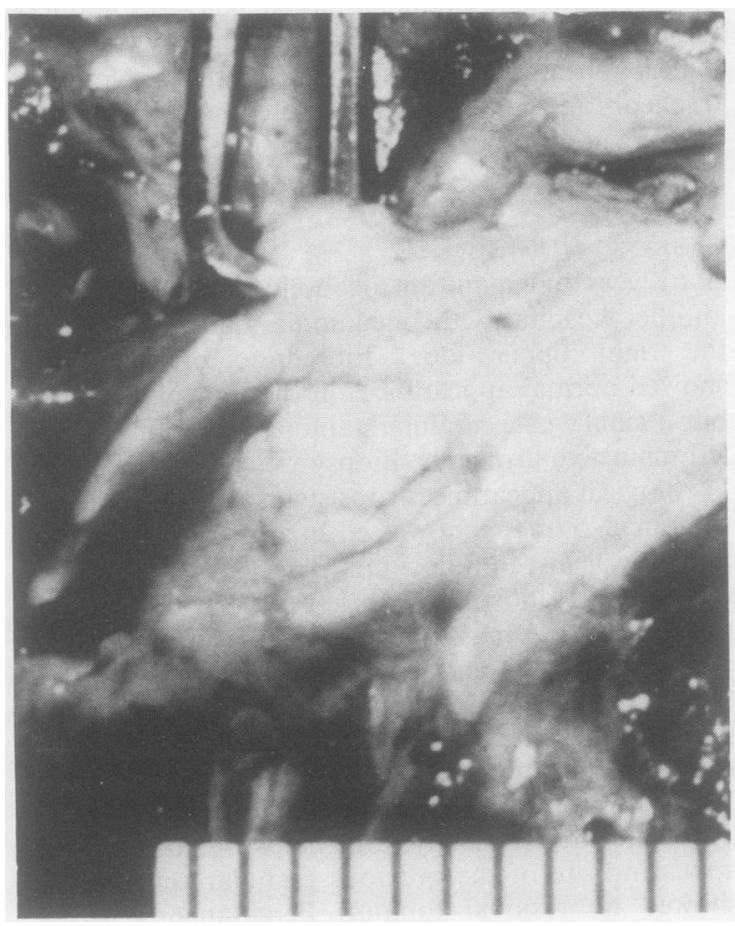

Resected specimen from case 3: A pale, nodular, discrete lesion $(1 \times 1 \mathrm{~cm})$ is evident in the right lower lobe segmental bronchus. (Divisions on the scale are $5 \mathrm{~mm}$ ). cases have been reported, of which only $6 \%$ (range -0 $0-10 \%$ ) affected the tracheobronchial tree. ${ }^{2-6}$ 등 Although the histogenesis of this tumour remains $\frac{\bar{m}}{\bar{m}}$ controversial, it is no longer generally believed to $\widehat{\Phi}$ originate from muscle cells; the original term "myoblastoma" has been replaced by the descriptive "gran- $"$ " ular cell tumour." Recent histochemical ${ }^{7}$ and electron $\vec{\circ}$ microscopic ${ }^{89}$ studies have lent support to a neuro- $\overrightarrow{\vec{\omega}}$ ectodermal origin of the granular cells, which may resemble Schwann cells undergoing Wallerian degen- $-\vec{x}$ eration.

Granular cell tumours are usually small, firm, $\stackrel{\oplus}{\oplus}$ solitary, non-encapsulated nodules with no dis- $\vec{N}$ tinguishing external features. The histological appear- 0 ance is characteristic and consists of nests and sheets of large, distinctly bordered ovoid and polygonal cells 은 that contain a finely granular, eosinophilic cytoplasm. $\overrightarrow{-}$ These granules apparently are lysosomal structures. ${ }^{10}{ }_{\mathbb{D}}$ The nuclei are usually small and uniform, and tend toळ be pyknotic and centrally located. The cells are $\frac{3}{0}$ arranged in small clusters delineated by basement $\stackrel{\mathbb{Q}}{\mathscr{}}$ membrane material. Myelinated nerve bundles, often $\vec{\bullet}$ arranged in concentric whorls and surrounded byo granular cells, are seen in about half of the cases.

At bronchoscopy most lesions have been foundo within the trachea or a mainstem bronchus, $47 \%$ on the right side, $42 \%$ on the left, and $15 \%$ within the trachea or carina (table 1). The tumour has most $\frac{\circ}{\Phi}$ often been described as a solitary, discrete endo- 2 bronchial nodular mass, usually pale pink, grey, orō yellow, but may also resemble an infiltrating car- $\frac{3}{2}$ cinoma (table 2). The lesions reported had a mean diameter of $1.6 \mathrm{~cm}$, with a wide range of $0.4-6.5 \mathrm{~cm}$. Although complete occlusion of the bronchial lumen by the tumour is unusual, peribronchial invasion may lead to considerable endobronchial narrowing. Full thickness invasion of the bronchial wall has been 3 reported in about $40 \%$ of affected patients and should be suspected in large infiltrating lesions. Small poly- $\frac{\mathrm{O}}{3}$ poid or pedunculated tumours are unlikely to have extensive submucosal invasion. At the time of bronchoscopy $18 \%$ of patients have had multiple intra $\frac{D}{0}$ pulmonary lesions identified and $7 \%$ have had simultaneous extrapulmonary lesions, most frequently ato subcutaneous sites. Metachronous lesions at differentro sites within the tracheobronchial tree have been reported in two patients. ${ }^{1112}$ Because the tumour is ${ }^{\mathrm{\omega}}$ covered only by a thin layer of bronchial epithelium, results of forceps biopsy have been almost invariablye positive. Diagnostic cytopathological examination of bronchial washings is, however, unusual, and has been reported in only three patients. ${ }^{13-15}$ Squamous metaplasia of the overlying respiratory epithelium is found in about half of patients, and may occasionally resemble squamous cell carcinoma. Nevertheless, $\mathbb{R}$ squamous cell carcinoma overlying a granular celf 
Table 1 Tracheobronchial distribution of 82 granular cell tumours $^{4-611-1924-39}$

\begin{tabular}{lc}
\hline Location & No $(\%)$ \\
\hline Trachea and main carina & $13(15)$ \\
Right lung & $11(13)$ \\
Main bronchus & $11(13)$ \\
Upper lobe bronchus & $4(5)$ \\
Bronchus intermedius & $6(7)$ \\
Lower lobe bronchus & $2(2)$ \\
Segmental bronchus & \\
Left lung & $8(10)$ \\
Main bronchus & $7(8)$ \\
Upper lobe bronchus & $12(14)$ \\
Lower lobe bronchus & $4(5)$ \\
Segmental bronchus & $4(5)$ \\
Other & \\
\hline
\end{tabular}

Table 2 Bronchoscopic appearances of 93 granular cell tumours $^{4-6} 11-1924-39$

\begin{tabular}{lc}
\hline Description & No $(\%)$ \\
\hline Discrete endobronchial tumour & $37(40)$ \\
Infiltrating mass lesion & $12(13)$ \\
Raised plaque like, mucosal thickening & $12(13)$ \\
Others & $5(5)$ \\
Not seen at bronchoscopy & $5(5)$ \\
Not described & $22(24)$ \\
\hline
\end{tabular}

tumour has been reported only once, and that was on the vulva. ${ }^{16}$

Clinically, most patients have presented with recurrent or unresolved pulmonary infiltrates related to bronchial obstruction (table 3 ). The mean duration of symptoms from onset to diagnosis has been $11 \cdot 2$ months, varying with the presenting complaint: from one day in a case of haemoptysis to seven years with recurrent pneumonia. Twelve per cent of cases presented with an asymptomatic lung nodule or mass, and in $13 \%$ the tumour was discovered only incidentally at bronchoscopy performed for another indication, as in our second and third patients. Occasionally, endobronchial granular cell tumours have been found unexpectedly during evaluation of suspected bronchogenic carcinoma, but there is no clear relationship to lung cancer. Constitutional complaints are uncommon with granular cell tumours, and only $10 \%$ of patients have been reported to have lost weight.

Haemoptysis has been recorded in $25 \%$ of cases. Bleeding is usually minor, but massive haemoptysis has been reported. ${ }^{17}$ In most patients the mechanism for haemoptysis is largely unknown. Granular cell tumours rarely penetrate the bronchial mucosa, are not densely vascular, and have not been reported to erode bronchial vessels. Nevertheless, manipulation of the tumour can result in appreciable haemorrhage. ${ }^{1819}$ None of our patients was bleeding at
Table 3 Presenting clinical and radiographic features of tracheobronchial granular cell tumours: information from 68 cases $^{4-611-1924-39}$

\begin{tabular}{lc}
\hline Feature & No (\%) \\
\hline Haemoptysis & $17(25)$ \\
Recurrent pneumonia & $17(25)$ \\
Persisting pulmonary infiltrate, atelectasis & $14(20)$ \\
Chronic cough & $13(19)$ \\
Incidental bronchoscopy finding & $10(15)$ \\
Asymptomatic lung nodule or mass & $8(12)$ \\
Bronchiectasis or abscess & $6(9)$ \\
Unexplained chest pain & $6(9)$ \\
Normal chest radiograph & $4(6)$ \\
Unexplained dyspnoea & $3(4)$ \\
\hline
\end{tabular}

the time of bronchoscopy, and the bleeding resulting from forceps biopsy of their tumours was minimal. Including the present report (case 1), only three patients have been reported as having presented with haemoptysis and a normal chest radiograph. ${ }^{2021}$

Although most tumours grow slowly, frequently remaining unchanged radiographically for years, an occasional granular cell tumour has acted malignantly, giving rise to regional lymphatic and distant metastases. ${ }^{20-23}$ None of the malignant granular cell tumours, which have been reported in only 26 patients, was of bronchial origin. Half of the malignant tumours, however, metastasised to the lungs and, like other haematogenously disseminated neoplasms, metastatic granular cell tumours have also presented as extrabronchial peripheral pulmonary nodules.

Treatment of patients with endobronchial granular cell tumours has not been clearly defined. Difficulties in selecting the optimum therapeutic approach arise from uncertainties about their natural history and, because no study comparing the various alternatives has been reported, therapeutic decisions necessarily derive from anecdotal reports. Current therapeutic options include surgical resection, endoscopic removal, fulguration, and laser photocoagulation. Overall, surgical excision of the tumour mass has resulted in the highest cure rate. Of 20 surgically treated patients with long term follow up (mean 3.3 years, range 4 months to 12 years), only one was reported to have had symptomatic recurrence. Yet the optimum extent of surgery remains unclear. Most authors agree that when postobstructive parenchymal damage has occurred, segmental or lobar resection is indicated; in fact, such resection has been the most frequently used approach. When local resection of the mass is anatomically feasible, however, sleeve resection is considered to be the procedure of choice.

Less invasive therapeutic alternatives have also met with some degree of success. Endoscopic resection $(\mathrm{n}=13)$, fulguration $(\mathrm{n}=2)$, and laser photo- 
coagulation $(n=4)$ have been reported in 19 patients, ${ }^{11181924-38} 10$ of whom remained symptom free at follow up. There were six (32\%) documented recurrences-at 3 months, 5 months, 15 months, 2.5 years, 3 years, and 6 years. In three patients follow up information was not available.

Factors affecting tumour recurrence after treatment have not been fully identified, but Daniel and associates $^{39}$ noted that the likelihood of successful bronchoscopic removal is related to tumour size. Only the larger tumours $(1-2 \mathrm{~cm})$ recur, and full thickness invasion of the bronchial wall is found only when tumours exceed $8 \mathrm{~mm}$ in diameter. Thus smaller neoplasms may be treated by endobronchial resection, whereas larger tumours would require a broader surgical approach. Lack $e t a l^{2}$ found a $25 \%$ recurrence rate in incompletely excised extrapulmonary lesions. Because of the slow growth rate of these tumours, treatment should not be considered successful until completion of at least two years of follow up, which has been the mean time for recurrence.

Extended symptom free intervals have also been observed in some untreated patients. Of seven untreated patients, four remained symptom free after two years. Spontaneous resolution, however, has been documented in only one previous case. Although spontaneous resolution of the tumour after transbronchoscopic biopsy was likely in our second case, the lesion might have been completely excised by the forceps at the time of biopsy. Thus in selected patients with multiple lesions, in patients in whom a small tumour is detected incidentally, or when thoracotomy presents high risks, reasonable alternatives are endoscopic laser photocoagulation, fulguration, and observation alone, all with periodic endoscopic surveillance.

We thank Dr Sui-Lit Yu, of Lake Charles, Louisiana, for referring patient 2 to us; Dr Ronald A Welsh for reviewing the pathological material; and Charles Chapman, Debbie F McNamara, and Joy Eschmann for their assistance in the preparation of the manuscript.

\section{References}

1 Abrikossoff A. Uber Myome, ausgehend von der guergestreiften willkurlichen Musculatur. Virchows Arch (Path Anat) 1926;260:215.

2 Lack EE, Worsham GF, Callihan MD, Crawford GE, Klappenback S, Rowden G, Chun B. Granular cell tumor: a clinicopathologic study of 110 patients. $J$ Surg Oncol 1980;13:301-16.

3 Strong EW, McDivitt RW, Brasfield RD. Granular cell myoblastoma. Cancer 1970;25:415-22.
4 Paskin DL, Hull JD, Cookson PJ. Granular cell myo blastoma. A comprehensive review of 15 years experience. Ann Surg 1972;175:501-3.

5 Peterson LJ. Granular cell tumor. Review of the litera $\overline{\bar{T}}$ ture and report of a case. Oral Surg 1974;37:728-35. $₫$

6 Vance SF, Hudson RP. Granular cell myoblastoma clinicopathologic study of forty-two patients. $\mathrm{Am} L$ Clin Pathol 1969;52:208-11.

7 Rode J. Immunohistochemical staining of G.C.T. for neuron-specific enolase: evidence in support of $\underset{\mathrm{W}}{\mathrm{S}}$ neural origin. Diagnost Histopathol 1982;5:205-11. $\risingdotseq$

8 Moscovic EA, Azar HA. Multiple granular cell tumors ("myoblastomas"): case report with electron micro $\rightarrow$ scopic observations and review of the literature $\vec{N}$ Cancer 1967;20:2032-47.

9 Fisher ER, Wechsler H. Granular cell myoblastomamisnomer: electron microscopic and histochemicab evidence concerning its Schwann cell derivation and nature (granular cell Schwannoma). Cancer 1962;15:936-54.

10 Robbins SC, Cotran RS, Kumar V. Pathologic basis of disease. Philadelphia: WB Saunders Co, 1984:1316-7

11 Schwartzberg DG, Al-Bazzaz FJ, Cassel J, et al. Multi®ِ ple granular cell tumors of the bronchi. Am Rev Respir. Dis 1979;120:193-6.

12 O'Connell DJ, MacMahon H, DeMeester TR. Multi centric tracheobronchial and esophageal granular celp myoblastoma. Thorax 1978;33:596-602.

13 Glant MD, Wall RW, Ransburg R. Endobronchial gran ular cell tumor: cytology of a new case and review ol़ the literature. Acta Cytol 1979;23:477-82.

14 Thomas L, Risbud M, Gabriel JB, Caces W, Chauhar? PM. Cytomorphology of granular cell tumor of the $\overrightarrow{\bar{B}}$ bronchus. A case report. Acta Cytol 1984;28:129-32.3

15 Medart WS, Whiddon MC, Shanbhag N, et al. Granulap cell myoblastoma of the bronchus. $J$ Thoracardiovase Surg 1973;65:214.

16 Chiodi NE, Siegel IA, Guerin PF, McCaughan D Granular cell myoblastoma of the vulva and loweñ respiratory tract. Obstet Gynecol 1957;9:472-80.

17 Mullen CV, Hewan-Lowe K, Gilman MJ. Massive hemoptysis associated with granular cell tumor of the bronchus. South Med J 1983;76:1452.

18 Ramsey JH. Bronchial granular cell myoblastomas. Arch Otolaryngol 1962;62:81-3.

19 Kommel RM, Bernstein J. Granular cell myoblastoma of the bronchus. Report of a case. Harper Hosp BuI 1960;18:20-4.

20 Gamboa LG. Malignant granular cell myoblastoma Arch Pathol 1955;60:663-8.

21 Cadotte M. Malignant granular cell myoblastomaㄱ Cancer 1974;33:1417-22.

22 Usui M, Ishii S, Yamawaki S, Sasaki T, Minami A Hizawa K. Malignant granular cell tumor of the radia nerve. Cancer 1977;39:1547-55.

23 Steffelaar JW, Nap M, von Haelst UJ. Malignant granu lar cell tumor: report of a case with special reference tod carcinoembryonic antigen. Am J Surg Pathol 19820 6:665-72.

24 Symbas PN, Logan WD jun, Vakil HC. Granular ce myoblastoma of the bronchus. Ann Thorac Sur\& 1970;9:136-42. 
25 Valenstein SL, Thurer RJ. Granular cell myoblastoma of the bronchus: case report and literature review. J Thorac Cardiovasc Surg 1978;76:465-8.

26 Benson W. Granular cell tumors (myoblastomas) of the tracheobronchial tree. J Thorac Cardiovasc Surg 1966;52:17.

27 Nora P, Novak GM, Holmes GW. Granular cell myoblastoma of the bronchus: report of two cases and review of the literature. J Int Coll Surg 1961;35:651-8.

28 Suzuki C, Oshibe M, Nagashima Y. Granular cell myoblastoma of the bronchus: report of a case with treatment by upper lobectomy and sleeve resection of the stem bronchus. J Thorac Cardiovasc Surg 1971;61: 271-7.

29 Kramer R. Myoblastoma of the bronchus. Ann Otol Rhinol Laryngol 1939;48:1083-6.

30 Caulet T, LeMelletier J. Tumeurs a cellules granules a localizations bronchique et lingulae associées. Ann Anat Pathol 1959;4:154-8.

31 Rojer CL. Multicentric endobronchial myoblastoma. Arch Otolaryngol 1965;82:652-5.

32 Daniel GS. Multiple granular cell tumors of the bronchi-treatment with laser. Am Rev Respir Dis
1979;120:193-6.

33 McClain WC, Olsen GN, Wooldridge D, Almond $\mathrm{CH}$, Boykin AB. Endotracheal granular cell myoblastoma: a failure of laser therapy. Chest 1984;86:136-7.

34 Cooper JAD jun, Arora NS. Multiple granular cell myoblastomas of the bronchial tree. South Med J 1982;759:491-2.

35 Ivatury R, Shah D, Ascer E, Krinivasan K, Hereaud J, Rohman M. Granular cell tumor of larynx and bronchus. Ann Thorac Surg 1982;33:69-73.

36 Young CD, Gay RM. Multiple endobronchial granular cell myoblastomas discovered at bronchoscopy. Hum Pathol 1984;15:193-4.

37 Thaller S, Fried MP, Goodman ML. Symptomatic solitary granular cell tumor of the trachea. Chest 1985;88:925-8.

38 Mikaelian D, Israel H, Cohn H, Lebronian Z. Granular cell tumor of the trachea. Ann Otol Rhinol Laryngol 1984;93:457-9.

39 Daniel TM, Smith RH, Faunce HF, Sylvest VM. Transbronchoscopic versus surgical resection of tracheobronchial granular cell myoblastomas. $J$ Thorac Cardiovasc Surg 1980;80:898-903. 